\title{
Localization of Metadata Elements in the Art Museum Community
}

Youngjoon Nam*

Seungmin Lee**

\begin{tabular}{|c|c|c|}
\hline & Contents & \\
\hline 1. Introduction & & 2 Clarification of the Meaning of \\
\hline 2. Background of This Research & & Elements \\
\hline $\begin{array}{l}\text { 3. Metadata Schemes Currently Used in } \\
\text { South Korea }\end{array}$ & & $\begin{array}{l}3 \text { Paradigm Shift to Collection } \\
\text { Management }\end{array}$ \\
\hline $\begin{array}{l}\text { 3.1 Categories for the Description of } \\
\text { Works of Art (CDWA) }\end{array}$ & $\begin{aligned} \text { 5. } \mathrm{L} \\
\mathrm{tl}\end{aligned}$ & $\begin{array}{l}\text { ocalization of Metadata Elements for } \\
\text { e Art Museum Community }\end{array}$ \\
\hline 3.2 Visual Resource Association Core & & 1 Selection of Metadata Standards \\
\hline Categories (VRA Core) & & 2 Extraction of Core Elements \\
\hline 3.3 Dublin Core & & 3 Categorization of Core Elements \\
\hline 3.4 U-Museum & & 4 Survey and Consultation \\
\hline 4. Considerations of Generating Metadata & & 5 Generation of a Set of Metadata \\
\hline Elements for the Art Museum Community & & Elements \\
\hline 4.1 Characteristics of Art Works & 6 . & Conclusion \\
\hline
\end{tabular}

\begin{abstract}
The art museums in South Korea are mostly small-scaled institutions with small amount of art works. Thus, internationally accepted metadata standards such as CDWA and VRA Core may not be efficient to manage their collections. Because of these distinct local characteristics, there is a need to create a set of metadata elements that can be used for the art museum community in the country. This research aims to propose a set of metadata elements customized to fit into the context of small-scaled art museums in South Korea. The construction of the element set was not from scratch but on the basis of existing standards such as CDWA, VRA Core, and Dublin Core. By identifying core elements that are indispensable in describing art works and collecting opinions of experts in art museums, the proposed set of metadata elements is expected to support the operation and management of art works and satisfy the localized needs of the art museum community.
\end{abstract}

Keywords: Art Museum, Metadata Element, CDWA, VRA Core, Dublin Core, U-Museum

* Professor, Dept. of Library and Information Science, Chung-Ang University, South Korea (namyj@cau.ac.kr) (First Author)

** Full-time Instructor, Dept. of Library and Information Science, Chungnam National University, South Korea (ableman@cnu.ac.kr) (Corresponding Author) 논문접수일자: 2012년 4월 2일 최초심사일자: 2012년 4월 17일 게재확정일자: 2012년 5월 14일 한국문헌정보학회지, 46(2): 175-197, 2012. 〔http://dx.doi.org/10.4275/KSLIS.2012.46.2.175] 


\section{Introduction}

The term metadata, generally defined as 'data about data,' has become one of the basic concepts in describing and managing various types of resources in the library community. It has also been adopted in the art museum community in order to describe, organize, and manage collections of art works. Currently, many metadata standards are used in the community by providing structured schemes and elements in order to support the management of the art works.

In South Korea, many of art museums has adopted internationally accepted standards such as Categories for the Description of Works of Art (CDWA) and used them to describe and manage heritage and art works in their collections. However, most art museums in the country are small-scaled and maintain relatively small number of art works in their collection. Furthermore, most of art museums focus on specific types rather than broad range of art works. Because of these distinct local characteristics, existing standards often show limitations in supporting description and management of art works in the country. They are mostly international standards designed to be used in large-scaled general art museums and contain too many detailed elements to be used in small-scaled art museums. Another problem is that art museums in South Korea have their own purposes in management and organization of their collections. This results in the situation that those standards may not fully satisfy the unique purposes of art museums in the country and only provide simple resource descriptions, although they provide plenty of detailed elements.

The National Museum of Contemporary Art (MOCA) of South Korea constructed U-Museum system, a nation-wide metadata standard, on the purpose of satisfying unique needs of art museums in the country. However, it also has several limitations to be used as a national standard. Although it provides comprehensive elements to describe various types of art works, it is still biased to satisfy the needs of large-scale art museums. In addition, there is lack of elements that can support the description of new types of art works. Therefore, there have been increasing needs for more sophisticated and standardized tools that can fit into the context of small-scaled art museums in the country.

This research proposes a specified set of metadata elements that can be used as a basis of generating metadata scheme which reflects the unique characteristics of the art museum community in South Korea and supports the management of collection of art works. 


\section{Background of This Research}

In recent years, art museums have faced with challenges to respond expectations from their community and need to provide detailed description by reflecting multiple aspects of a specific art work. The art museum community have adopted new and emerging technologies in response to these needs and to provide better services for the public (Bearman \& Geber, 2007).

Metadata is one of the tools to satisfy these needs of the art museum community. In the current information environment where a variety of resources coexist with multiple, heterogeneous formats of description, metadata is nailed as the most feasible tool to improve the management of resources (Nam \& Lee, 2010). Although metadata was intended to refer to simple data description when it was introduced (Sundgren, 1973; Sundgren, 1975), the term has been applied in many fields and its meaning has gradually changed: Originally used to describe digital resources on the Web, metadata is now employed as a tool to identify and manage any type of resource, including art works and realia. This concept of metadata has been applied in the art museum community and many metadata standards have been developed in describing art works, including Categories for the Description of Works of Art (CDWA), Encoded Archival Description (EAD), Visual Resource Association Core Categories (VRA Core) as well as Dublin Core. However, different art museums have different types of art works and different needs of resource description. To satisfy these heterogeneous needs and to cover all types of works, many art museums have adopted different standards and customized them to satisfy their own purposes. In addition, small-scaled localized art museums, especially those in South Korea, have their own characteristics different from large-scaled cultural heritage institutions in other countries. They manage specific types of art works in their collection and have distinct purposes in accordance with the tradition of South Korea. In this circumstances, internationally accepted standards may not sufficiently reflect the unique and localized characteristics of small-scaled art museums in the country. Another problem is the description of new types of art works. Different from the traditional format of art works, the new type of work may require additional parts to be displayed and more detailed aspects to be described. However, existing standards show limitations in describing these heterogeneous types such as multimedia, multi-dimensional and installation art works because they were originally designed for traditional and static art works. There are few concrete formats for descriptive information that can comprehensively encompass all those heterogeneous types of art works.

National Museum of Contemporary Arts (MOCA) of South Korea created U-Museum system as a national standard based on its own metadata scheme in order to address these problems 
and to provide comprehensive and detailed information of its collection. However, like other existing standards, it is limited in describing new types of art works such as media art, installation art or the one that combined several types of works because of its rigid structure and strict rules.

In these reasons, it is necessary to have a metadata scheme specified in the context of South Korea where there are many small-scaled art museums with distinct characteristics. It should also support the management of art works for different levels of art museums.

\section{Metadata Schemes Currently Used in South Korea}

Many metadata standards are currently used in the art museum community in South Korea. Among those standards, CDWA, VRA Core, and Dublin Core are the mostly used ones in the country.

\subsection{Categories for the Description of Works of Art (CDWA)}

Categories for the Description of Works of Art (CDWA) was developed in 1994 by the Art Information Task Force (AITF) under the sponsorship of the Getty Art History Information Program (AHIP) and the College Art Association (CAA). When CDWA was first proposed, it primarily focused on supporting the recording of information in such a way that it would be useful for scholarly research (Caplan, 2003).

CDWA was originally intended to be used by museums or archives. It was developed to provide common semantic categories and content rules through development of cross-community consensus on the basic elements for description of works of art. CDWA categories also describe the content of art databases by articulating a conceptual framework for information about art objects and provide a framework to which existing art databases can be mapped (Baca \& Harpring, 2006). AITF originally limited the types of objects to art works and images only; however, it currently covers various types of objects, including movable objects collected by museums, representations of such objects, performance art, architectures, pictures of original works, slides, visual representation, and the like.

With these strengths in describing art works, CDWA has been broadly adopted by the art museum community as a international framework and a basis for a number of museum databases. In contrast, it is rarely implemented in its entirety because of its excessive comprehensiveness 
(Greenberg, 2003; Elings \& Waibel, 2007). In addition, its complexity can be obstacles in generating metadata records for small-scale art museums with small collections.

\subsection{Visual Resource Association Core Categories (VRA Core)}

Visual Resource Association Core Categories (VRA Core) was developed in 1995 by The Visual Resources Association (VRA) that is a multi-disciplinary organization dedicated to facilitating research and education in the field of image management under the educational and cultural heritage environments. The association indicated a problem that CDWA does not provide sufficient elements to describe images and visual works, although it contains broad range of elements in describing objects in museums. VRA Core was developed in order to complement the weaknesses of CDWA and to support the description of visual works, including buildings, crafts, and other visual objects.

VRA Core is a data standard for the cultural heritage community. It consists of a set of metadata elements that can be applied as many times as necessary to create records for works of visual culture and the images that document them (VRA Core Data Standards Committee, 2011). Initially, VRA Core contained two separate element sets: one for the description of works and another for the description of visual documents. In organizing sets of its elements, VRA Core adopted the concept of 'core' to be used as the middle class of resource description between low-level and full-level description.

It was originally designed as a metadata standard to describe and manage visual collection using 21 categories of metadata elements (VRA Core 1.0). Since version 1.0, VRA Core has been updated and expanded to describe other types of objects than visual resources. Currently, version 4.0 is in use and consists of 17 core elements that are all optional and repeatable, some of them with qualifiers. They are used to describe works of visual or their surrogate images.

VRA Core has been internationally accepted as a powerful tool in describing visual works. Although the detailed element set provides plenty of descriptive elements in describing various types of resources, its strict and complex rules require experts' knowledge when applied to localized collections, especially in small-scaled art museums, which may need only some of the core elements.

\subsection{Dublin Core}

Dublin Core is a simple but effective element set for describing a wide range of resources. 
It was introduced as an internationally agreed-upon set of elements in order to define the core elements that are appropriate for describing and retrieving networked resources but are simple enough to be used by the author of any networked resources (Hilmann, 2005). In subsequent specifications, however, Dublin Core has expanded its range of describable objects to cover all types of resources, including art works.

Originally, Dublin Core was implemented through the use of HTML, thus allowing anyone to be able to fill in the Dublin Core elements. More recently, it has been implemented using XML and RDF. Dublin Core is also very flexible when filling in the element values because all elements are both optional and repeatable. In addition, the standard itself is format-independent, meaning that it is not tied to any single data representation or particular content rule (Lanzi \& McRae, 2007).

With these strengths, the art museum community has accepted Dublin Core, especially when it was problematic to apply other metadata standards with strict rules or complex structures. Its simple set of elements can be easily applied in the art museums with small collections without experts' knowledge. In contrast, because Dublin Core is not originally designed for the art museum community, it does not provide enough elements specified to describe detailed aspects of art works. In addition, metadata record generated using Dublin Core is ambiguous because of the broad range of meanings embedded in each Dublin Core element.

\subsection{U-Museum}

The National Museum of Contemporary Art (MOCA) is a national institute that collects, preserves, displays and investigates various works of art in South Korea. It also promotes cultural exchange across nations so that aims to facilitate the cultural services in the country.

As national art museum, MOCA has developed U-Museum system in 1995, which is now accepted as a main system for organizing and managing art information. It was originally designed to provide Web-based integrated information services for art works and to provide services as a digital art museum with high-quality of colors. The development of U-Museum system was based on a standardized classification for art works that supports the categorization of descriptive elements. MOCA initially divided the areas of art works in seven categories and focused on the creator of each work. It has been expanded into 10 categories (Korean painting, architecture, crafts, picture, calligraphy, sculpture, drawing, print, design, and new media) in order to focus on art work itself instead of its creator. Based on these categories, descriptive elements have 
been defined to construct $U$-Museum system as a standardized metadata standards for art works. U-Museum system currently has 88 elements that can be divided into three categories: 38 elements related to managing works of art, 26 elements in describing creators, and 24 elements related to exhibitions.

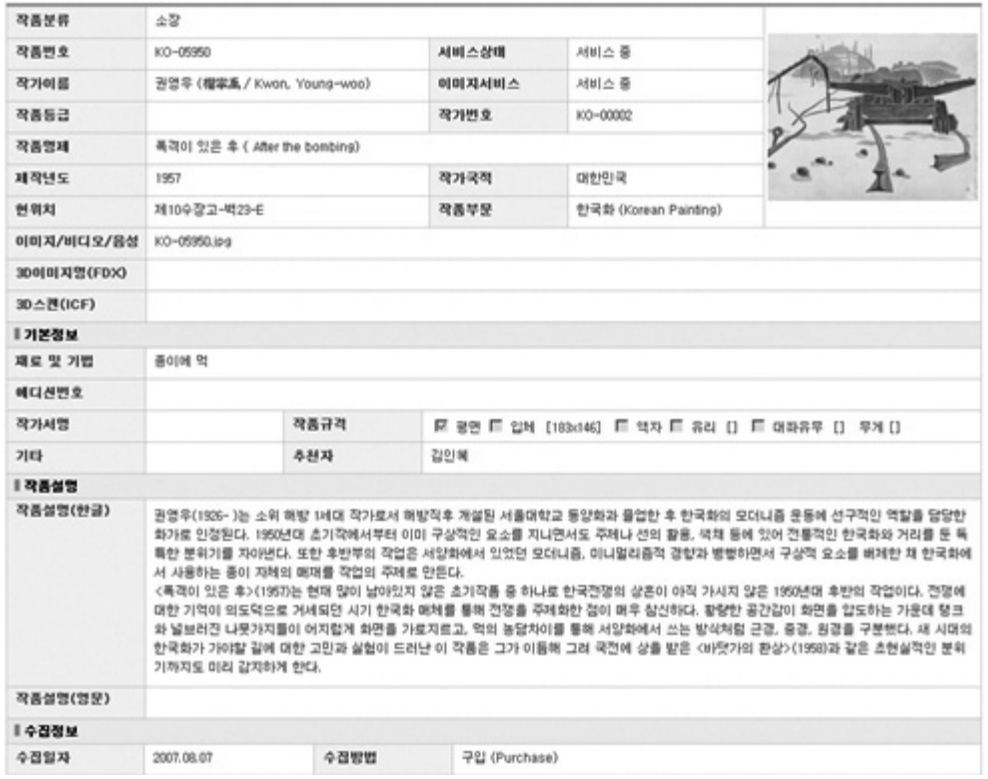

〈Figure 1〉 Example of a Metadata Record Displayed in U-Museum System

As shown in Figure 1, U-Museum provides information about art works using its descriptive elements. Theoretically, this system should be able to generate all the information related to its collection of art works regardless of their types. However, it could not represent all attributes of its collections because of the lack of comprehensiveness. The meaning of each data element is too ambiguous or, in some cases, too specific when assigning values extracted from each art work. It also could not reflect the unique and localized needs of art museums in South Korea because it was constructed mainly based on CDWA and EAD structure, which do not consider the contextual uniqueness of small-scaled art museums. In addition, individual elements are used several places in the structure without any specific rule, which results in the inconsistent structure of the system. Therefore, U-Museum system may not be considered as a metadata scheme but an enumeration of descriptive elements extracted from existing metadata standards. 


\section{Considerations of Generating Metadata Elements for the Art Museum Community}

The analysis provided above describes the strengths and weaknesses of existing metadata standards in the context of art works in South Korea. To address the problems of the current systems and to provide reliable and consistent information of art works, it may be necessary to have more sophisticated and powerful metadata scheme that can fit into the small-scaled art museums. It also needs to be flexible enough to cover different types of art works, including new and complex format of works. This research proposes a set of metadata elements that can reflect the unique characteristics of art works and the distinct context around the art museum community in South Korea.

\subsection{Characteristics of Art Works}

In generating the element set, it may be required to consider and identify the unique characteristics of art works. The collections in art museums consist of various types of art works, including drawings, sculptures, installation arts, and crafts. Each type has its own unique characteristics extremely different from others. Therefore, the elements adopted in art museums should be able to comprehensively deal with these heterogeneous aspects of each type of works (Kalay, Kvan \& Affleck, 2007).

In addition, compared to traditional resources such as books, it is difficult to explicitly identify attributes that can be assigned as values of elements. This is because art works usually do not contain text to represent the contents of the work and represent the contents in an abstract or artistic way. Goodman (1976) argues that works of art do not possess the properties of a language such as disjointness and differentiation. Text has an advantage over the visual works in that its syntax lends itself to analysis. The components and properties of visual works, on the other hand, cannot be extracted with the same ease and they are rarely explicitly labeled (Neugebauer, 2005). Therefore, the meaning of elements for describing works of art should be clear enough to be assigned to ambiguous and non-linguistic attributes of those works.

\subsection{Clarification of the Meaning of Elements}

As mentioned above, art works do not provide explicit contents that can be extracted directly 
from them. In this reason, the resource description can be biased according to the expert's knowledge during the description process or selection of elements. To remove this difficulty, the meaning of each element should be clearly prescribed in a commonly accepted manner. Another way to overcome this difficulty is to provide categories of the types of art works. By categorizing resource types and placing related elements under each category, semantic context can be established and the meaning of each element can be appropriately prescribed.

Another consideration when describing art works is that, in many cases, each art work consists of many additional parts associated with the display, preservation, management, and change of its location. A set of elements should be able to deal with these operations related to the art work. The elements related to an operation needs to be grouped together so that the staff can easily retrieve and utilize the description of the operation. Semantic categories of elements can support these operations by establishing element relationships and clarifying the meaning of each element.

\subsection{Paradigm Shift to Collection Management}

Previously, description of art work itself has been the core function of the systems in art museum community. With the technical development of operations related to art works, however, it may also be necessary for the systems to support the management and organization of art works in their collections, including history, display, related exhibitions, preservation, repair, and acquisition of those works. In this changed environment, the management and administration of the collections have been turned out to be one of the cores of the systems. These functions can support the organization and utilization of art works and related records, which can facilitate better cultural services for the public. To achieve this conceptual shift in the art museum community, a set of elements should support the collection management by describing each operation of art museums, including generation and management of metadata record and resource description.

\section{Localization of Metadata Elements for the Art Museum Community}

This research focuses on generating a set of metadata elements that can be suitable for the art museum community in South Korea, instead of constructing a concrete metadata scheme. 
The art museums in the country are under different cultural context from other countries so that may need to have distinct elements to fit into the context. Therefore, this research is limited to propose a set of customized and/or specified set of metadata elements to fit into the unique needs of the art museum community of the country.

\subsection{Selection of Metadata Standards}

To reflect the concerns of the art museum community and to generate a set of descriptive elements, the first step would be the selection of existing metadata standards. This is because existing standards contain plenty of metadata elements that can be used in describing various aspects of art works. By utilizing existing standards, the generation of the element set in this research is not from scratch but from cannibalizing elements from existing standards.

Three criteria were applied to limit the range of possible standards, which are (1) currently in use in the art museum community in South Korea; (2) able to deal with various types of art works, not limited to a specific type; and, (3) designed for general use rather than for a specific context. Based on these criteria, three standards were selected: CDWA, VRA Core 4.0, and Dublin Core.

Among these standards, CDWA and VRA Core 4.0 are used to describe all types of both static and dynamic art works and broadly adopted all over the world. In addition, they can be used to expand the detailed descriptions of art works when revising or extending the elements in existing database systems or when constructing new systems (Attig, Copeland \& Pelikan, 2004). In contrast, Dublin Core provides only 22 elements with qualifiers in describing resources. Each element has broad range of meaning compared to the detailed and specified element sets in CDWA and VRA Core 4.0. However, this broad meaning can be effective if it is used to categorize and encompass interrelated elements with specific range of meanings. In this reason, this research adopted Dublin Core element set as a basis of element categorization when constructing semantic categories of related elements.

\subsection{Extraction of Core Elements}

When generating a set of elements for the art museum community, it is necessary to have sufficient elements to describe unique aspects of art works. Among those elements, there may be core elements that are essential in describing art works and generating metadata records. In 
order to identify the core elements, the elements that are commonly used across standards were extracted. If more than one standards contain the elements with the same meaning, it may be considered as an essential or required element in describing any type of art work and tend to be required in generating metadata record. These common elements may have important meanings and can be considered as core elements in describing art works. These core elements can provide semantic context around each element in order to prevent the abuse of metadata elements by an art museum and can also provide enough flexibility for each institution to generate its own records.

In identifying core elements, this research conducted one-to-one mapping across elements in the selected standards. Through the mapping process, commonly used elements were extracted that can be considered essential in describing art works. However, each standard has different structure and syntax in the use and arrangement of its descriptive elements. These differences may affect the meaning of an element according to its location under its structure and representation based on its syntax. Another consideration of element mapping is the range of meaning in each element. CDWA and VRA Core 4.0 provide elements with detailed and specified meanings, whereas Dublin Core elements have broad range of meanings even if those elements represent the same or similar meanings. These different levels of granularity made it difficult to identify the same or similar meaning in different standards. It can also affect the semantics of each element even when the elements in different standards have the same label and definitional meaning. To mediate these potential inconsistency, the structure and syntax were also considered during the mapping process.

By considering these difficulties, this research conducted one-to-one mapping between CDWA and VRA Core 4.0. Dublin Core elements were then mapped with the results of the element mapping between CDWA and VRA Core 4.0 because Dublin Core elements encompass the specific meaning of the elements in other standards and can function to categorize semantically related elements from those standards. The results of element mapping show that 71 elements were identified to be commonly used between CDWA and VRA Core 4.0.

\subsection{Categorization of Core Elements}

The extracted common elements were then grouped into three broad types in order to specify their semantic functions in describing works of art: descriptive, managemental, and administrative types. The descriptive type refers to the elements that are used to describe substantial aspects 
of an art work, whereas managemental type indicates the elements that can be used to manage and organize art works. Administrative type is related to the operation of metadata records for each art work.

The common elements placed under each type needed to be further categorized according to their semantic similarities. Dublin Core elements were used to provide criteria for semantically categorizing those extracted common elements. In categorizing the common elements, Dublin Core element were applied as main criteria by providing space for categories where the same or similar elements can be related and grouped together. During the categorizing process, this research removed some elements from Dublin Core element set and added some categories. As a result, the 71 common elements were semantically categorized into 19 categories regardless of their superficial meanings represented by their labels (see Table 1).

〈Table 1〉 Types and Categories for Grouping Common Elements

\begin{tabular}{c|l}
\hline \multicolumn{1}{c|}{ Types } & \multicolumn{1}{c}{ Categories } \\
\hline Descriptive Elements & $\begin{array}{l}\text { Creator, Contributor, Title, Date, Relation, Type, Description, Exhibition, Coverage, } \\
\text { Format }\end{array}$ \\
\hline Managemental Elements & $\begin{array}{l}\text { Rights information, Subject information, Source information, Rental information, } \\
\text { Digitization information }\end{array}$ \\
\hline Administrative Elements & Identifier \\
\hline
\end{tabular}

Dublin Core provide 'publisher' as one of the main elements. In the context of art works, however, publisher is usually same as creator. Instead, it may be required to describe the information about the exhibition where the art work had been displayed for various purposes. In this reason, this research removed the element 'publisher' and added new category 'exhibition.' Another element considered was the element 'language.' In describing art works, language is rarely used because works of art usually represent their contents using non-linguistic tools. Therefore, this research also removed the element 'language.' In addition, some new categories were added that are spefific to art works. These categories include information about rental, digitization, location, and recovery of works of art, which are not provided by Dublin Core element set.

Some categories were applied in semantically different ways from Dublin Core elements although they have the same or similar labels as Dublin core elements. The category 'coverage' means the history of exhibition where a work of art was displayed. The category 'source' indicates how a work of art was collected by an art museum. The category 'subject' covers the periodic and social background that affected the creation of an art work. 
After setting up these categories, each of the extracted common elements was assigned to semantically related category. However, some semantic problems still exist in the assigning process. The categories based on Dublin Core element set could not provide art work-specific categories so that there have been difficulties semantically assigning common elements to the 19 categories. To address these difficulties, the categorization process focused on the semantic functions of elements when describing an art work (see Table 2).

〈Table 2〉 Categorization of the Extracted Common Elements

\begin{tabular}{|c|c|c|}
\hline Types & Categories & Common elements \\
\hline \multirow{11}{*}{ Descriptive Elements } & Creator & $\begin{array}{l}\text { name, pen name, nationality, date, gender, educational } \\
\text { background, affiliation }\end{array}$ \\
\hline & Contributor & person name, institution name, role \\
\hline & Title & title \\
\hline & Date & date of beginning creation, date of ending creation \\
\hline & Description & $\begin{array}{l}\text { size, edition, weight, material, duration, quantity, } \\
\text { additional part }\end{array}$ \\
\hline & Relation & related resource \\
\hline & Type & genre, style \\
\hline & Explanation & by author, by reviewer, background, method, \\
\hline & Exhibition & name of exhibition, topic of exhibition \\
\hline & Coverage & place of creation, place of display, period of display \\
\hline & Format & format \\
\hline \multirow{8}{*}{ Managemental Element } & Rights information & $\begin{array}{l}\text { copyright ownership, current ownership, previous } \\
\text { ownership }\end{array}$ \\
\hline & Subject information & periodic background, social background \\
\hline & Source (acquisition) & $\begin{array}{l}\text { acquisition method, acquisition date, acquisition price, } \\
\text { selling price }\end{array}$ \\
\hline & Rental information & $\begin{array}{l}\text { rental period, rental institution, rental fee, rental } \\
\text { responsibility }\end{array}$ \\
\hline & Digitization information & digitization method, digitization copyright \\
\hline & Location information & $\begin{array}{l}\text { reason for changing location, date for changing location, } \\
\text { current location, previous location, }\end{array}$ \\
\hline & Specific information & $\begin{array}{l}\text { storage consideration, moving consideration, exhibition } \\
\text { consideration }\end{array}$ \\
\hline & Recovery information & $\begin{array}{l}\text { recovery date, reason for recovery, recovery part, } \\
\text { responsibility of recovery }\end{array}$ \\
\hline Administrative Element & Identifier & registration number, record number \\
\hline
\end{tabular}

As shown in Table 2, this categorization makes a category semantically distinct from other categories. Through the inductive approach for categorizing element, related categories and elements 
could be assembled under the same group.

Another characteristic of this categorization is the interoperability with internationally accepted standards such as CDWA and VRA Core. Because the elements in the categorization were extracted from those international standards, they can be interrelated with the elements in those standards.

\subsection{Survey and Consultation}

This research conducted a survey and consultation meeting based on the result of identification and categorization of common elements considered as core elements in describing works of art. The purpose of the survey and consultation was to identify whether the core elements are essential in describing art works and whether the element categorization is reasonable, especially in the context of small-scaled art museums in South Korea. It also had the purpose of collecting extensive opinions from the experts in the field in the art museum community. Total 32 experts from 20 art museums across cities in the country participated in the survey and face-to-face consultation meeting. The positions of those participants varied from art museum manager to art works specialist. The participating art museums were selected from both urban and rural areas in order to identify specific or unique needs of different levels or scales of art museums. The result of the survey were analyzed to identify whether each element is reasonable and applicable in the art museum community in the country.

After reviewing the categories of core elements, some of the participants pointed out ambiguous meaning of some categories so that they could not clearly understand which elements could be assigned under which category. For example, they suggested that the category 'type' and 'format' need to be clearly separated or to change its label using other term in order to represent their essential functions. Besides, they also concerned about the lack of elements that can support the management of their collections. They want to collection information about the history of each art work, current location, whether it had any experience of recovery or restoration, and how it was collected, etc. Another suggestion was that some of the categories need to be merged into one category in order to clarify the meaning of ambiguous elements. For example, the categories 'creator' and 'contributor' may not be differentiated in the context of art works and can be considered as one category. The participants expected that this merge of categories could make a set of categories mutually exclusive.

Except for these suggestions, the participated experts agreed to reflect the management of collections in metadata elements, although they suggested to adjust some elements in preserving and 
storing special art works. Additionally, they suggested to add some more elements that are not currently included in existing standards in order to satisfy their own distinct purposes. They tend to focus on the elements that can support the management and organization of collections by reflecting the distinct context of their art museums. The summary of the requests from experts in the art museums community is as below:

(1) The elements related to repair and restoration of impaired art works

(2) The elements that can describe the details of copyrights and ownership

(3) The elements related to detailed contact information of a (group of) person who is in charge of the management and administration of art works

(4) The elements that provide standard for collection management, especially for the art works in new media types

(5) The elements that indicate the current and future values of art works

(6) The elements that can describe both previous and current methods of preservation for each art works

(7) The elements to describe current condition of art works

(8) The elements that can provide information about periodic handling methods for long-term preservation of art works

(9) Comprehensive set of elements that can describe various new types of art works

(10) The elements that describe additional parts required in displaying art works

(11) The elements related to the educational background of creator

(12) The elements that can describe specific methods for storing and managing art works according to the types of works

(13) Need for the system that can support the management of specific types of works, especially solid, three-dimensional, and outside works, including the methods of preservation for those types of works

Most of these requests reflect the needs for management and maintenance of art works in their collections. The result appeared to be more specific and practical than the elements extracted from existing standards. It also shows the unique characteristics of the art museums community in South Korea that requires to have elements which can support maintaining and managing collections of small-scaled art museums. Although existing standards may already contain the elements that can satisfy these needs, those elements were needed to be semantically specified and used as 
core and/or mandatory elements.

\subsection{Generation of a Set of Metadata Elements}

Based on the core elements extracted from existing standards and the result of survey and consultation meeting with the experts, this research generated a specified and localized set of elements that can be used for collections of art works. By reflecting the opinions and suggestions from local experts, the initial set of elements were slightly changed by adding and/or removing some specific categories.

The element set consists of three broad types based on the semantic functions of embedded elements: descriptive, managemental, and administrative types. The descriptive type refers to the elements that are used to substantially describe specific aspects of an art work, whereas managemental type indicates the elements that can be used to manage and organize art works. Administrative type is related to the operation and management of metadata records for each art work. These types are placed at the top of the hierarchical structure of the proposed set of elements and encompass related categories of elements.

Each type was further divided into specific categories for clustering related elements. Descriptive type has seven groups of elements, managemental type with eight groups of elements, and administrative type has two element groups. Total 17 categories are placed under related type and specify the broad meaning of those types. Although these categories were generated based on the main elements in Dublin Core, the specific meanings of those categories were modified in order to fit into the context of small-scaled art museums.

Under each category, the generated elements are placed to substantially describe art works. In addition to the 71 elements extracted from CDWA and VRA Core 4.0, 41 elements were added in order to represent specific and detailed aspects of art works by reflecting the results of consultation.

Each category functions as conceptual group of related elements and provides semantic context for prescribing and clarifying the meaning of each element. It also functions as conceptual arrangement of semantically interconnected elements and do not have any actual value, which means they are not used to describe any art work. The substantial description of art works can be done by the elements embedded under each category. However, for some institutions, especially for small-scaled art museums that need to generate brief resource description, those categories can be used as descriptive elements and be assigned actual values. The full set of metadata elements 
is provided in Table 3,4 , and 5 .

〈Table 3〉Metadata Elements for Art Museum Community (Elements in Descriptive Type)

\begin{tabular}{l|l}
\hline 1. genre & 5. description \\
\hline 2. title & 5.1 measurement \\
\hline 2.1 source of title & 5.1 .1 plane \\
\hline 2.2 subtitle & 5.1 .2 dimension \\
\hline 3. date of creation & 5.2 weight \\
\hline 3.1 date of beginning & 5.3 material \\
\hline 3.2 date of completion & 5.4 type \\
\hline 4. creator & 5.5 edition \\
\hline 4.1 real name & 5.6 duration \\
\hline 4.2 pen name & 5.7 components of work \\
\hline 4.3 role & 5.8 series information \\
\hline 4.4 nationality & 5.9 style \\
\hline 4.5 birth place gender & 5.10 technique \\
\hline 4.7 date of birth/death & 5.11 inscription \\
\hline 4.7 .1 date of birth & 5.11 .1 use inscription \\
\hline 4.7 .2 date of death & 5.11 .2 location of inscription \\
\hline 4.8 educational background & 6. information about creation of work \\
\hline 4.9 contact information & 6.1 explanation of work \\
\hline 4.9 .1 phone & 6.1 .1 explanation by creator \\
\hline 4.9 .2 email address & 6.1 .2 explanation by others \\
\hline 4.9 .3 local address & 6.2 background \\
\hline & 7. related works \\
\hline & 7.1 related resource \\
\hline
\end{tabular}

As shown in Table 3, descriptive type consists of seven categories that can describe the characteristics of an art work itself. These categories and embedded elements reflect distinct needs of the art museum community. For example, some of the art museums suggested to add detailed elements that can describe the educational background of creator, which is reflected as the element 'educational background' under the category 'creator.' Another unique element is 'background' placed under 'information about creation of work.' The art museum community wanted to provide information about the social, historical, and periodical background of an art work. In addition, this research changed the label 'format' to 'genre' in order to precisely represent the type of an art work. The value of this element can be assigned from the 10 formats used in U-Museum system. 
〈Table 4〉 Metadata Elements for Art Museum Community (Elements in Managemental Type)

\begin{tabular}{|c|c|}
\hline 1. exhibition information & 4. copyright information \\
\hline 1.1 place of exhibition & 4.1 name of copyright holder \\
\hline 1.2 time of exhibition & 4.2 contact information of copyright holder \\
\hline 1.2.1 exhibition beginning date & 4.3 expiration of current copyright \\
\hline 1.2.2 exhibition ending date & 4.4 date of transfer copyright \\
\hline 1.3 name of exhibition & 4.5 other considerations of copyright \\
\hline 1.4 theme of exhibition & 5. digitization information \\
\hline 2. rental information & 5.1 allower for digitization \\
\hline 2.1 rental period & 5.2 responsibility of digitization \\
\hline 2.1.1 rental beginning date & 5.2.1 name of responsibility of digitization \\
\hline 2.1.2 rental ending date & 5.2.2 contact information \\
\hline 2.2 institution who rented work & 5.2 .3 role in digitization \\
\hline 2.3 responsibility of rental & 5.2.4 department of the responsibility \\
\hline 2.3.1 name of rental responsibility & 5.3 method of digitization \\
\hline 2.3.2 contact information of the rental responsibility & 6. location information \\
\hline 2.4 price for rental & 6.1 current location \\
\hline 3. acquisition information & 6.2 former location \\
\hline 3.1 (previous) ownership & 6.3 date of move \\
\hline 3.1.1 name of (previous) ownership & 6.4 reason of move \\
\hline 3.1.2 contact information of previous owner & 7. management information \\
\hline 3.1.3 history of ownership & 7.1 consideration in preservation \\
\hline 3.2 location (within institution) & 7.2 consideration in moving \\
\hline 3.3 information about purchasing works & 7.3 consideration in displaying \\
\hline 3.3.1 date of purchase & 7.3.1 subject \\
\hline 3.3.2 price of purchase & 8. recovery information \\
\hline 3.4 information about selling works & 8.1 part of recovery \\
\hline 3.4.1 date of selling & 8.2 cost for recovery \\
\hline 3.4.2 price of selling & 8.3 reason of recovery \\
\hline 3.5 method of acquisition & 8.4 responsibility of recovery \\
\hline 3.6 classification number & 8.4.1 name of the recovery responsibility \\
\hline 3.7 registration number & 8.4.2 contact information of the recovery responsibility \\
\hline
\end{tabular}

The elements under managemental type, shown in Table 4, are mostly designed to support the operation and management of the collections of art works. The elements were clustered by eight categories and most of them to provide 'information' about specific operations related to art works. The category 'exhibition information' contains elements related to any exhibition that an art work was displayed. They may have the values related to the history of the work. Another distinct category is 'acquisition information.' This category contains elements when and how acquired an art work, how much the art museum paid, and who previously owned the art work. 
In addition, the category 'management information' provides elements that contain information about considerations when preserve, change location of, and display an art work. This category and embedded elements provide information to support these operations.

〈Table 5〉 Metadata Elements for Art Museum Community (Elements in Administrative Type)

\begin{tabular}{l|l}
\hline 1. information related to record & 1.2 name of record creator \\
\hline 1.1 date of record creation & 1.2 .1 name of first record creator \\
\hline 1.1 .1 date of initial record creation & 1.2 .2 name of record modifier \\
\hline 1.1 .2 date of record modification & 1.3 number of record \\
\hline & 2. information about registration of work \\
\hline
\end{tabular}

The administrative type consists of two categories: 'information about record' and 'registration of works of art.' These categories are mostly used in management of records that generated by using the descriptive and managemental elements. Therefore, this type can be considered as meta-record and cannot exist in its own. It should be used with the generated record using the elements under descriptive and managemental types.

These relationships across types, categories, and elements establish hierarchical structure for the proposed set of elements. The types placed at the top of the structure prescribe the semantic range of the embedded categories and elements. The categories under each type establish relationships between similar elements and assemble related values extracted from actual art works. Each element is used to substantially describe the art work. In addition, an element in one record can be linked to the elements in other records if they share the same value. Through this link to the same value, an object can be linked to related objects and can improve the management of records and resources in the art museum community.

This proposed set of elements is customized to support the operation and management of collections in a specific situation, especially for the small-scaled art museums. A set of simple but essential elements is expected to enhance the efficiency of the generation of metadata records and the management of the collections of art works. In contrast to the simplicity, it contains elements that are indispensable in describing any type of art work. The identified core elements and the addition of essential elements suggested by the experts from art museums may satisfy the needs of small-scaled art museums. 


\section{Conclusion}

In recent years, the art museum community has adopted several metadata standards such as CDWA and VRA Core to describe their collections of art works. However, these standards were originally designed to satisfy the needs of large-scaled institutions by using a highly detailed set of metadata elements, which may not be appropriate for small-scaled art museums. To address these difficulties, this research proposed a set of metadata elements customized to fit into the distinct context of small-scaled art museums in South Korea.

A set of metadata elements proposed here consists of three broad types of elements: descriptive, managemental, and administrative. Each type was divided into several categories of elements based on their semantic relationships and functions to provide spaces for clustering related elements. Total 17 categories are placed under each type and specify the broad meaning of those types. Total 112 elements were placed under the categories and expected to substantially describe specific aspects of art works. This set of elements can be extended if there is a need to add more elements. It is also flexible enough to be applied in different types and scales of art museums by selectively using the proposed core elements. Although the set of core elements would provide enough flexibility for each art museum to generate their own records, it can also control the abuse of metadata elements by semantically prescribe the context around each element and refine specific meaning of it.

However, this research only proposed a set of elements for the description and management of the collections of art works. Because the element set does not provide a structured scheme for implementation, it was necessary to provide a data model that could incorporate those elements in a structured format. Further research may also require to reflect and specify collective intelligence among the art museum community when it creates metadata records for a specific object.

\section{References}

[1] Attig, John, Copeland, Ann, \& Pelikan, Michael. 2004. "Context and meaning: The challenges of metadata for a digital image library within the university." College \& Research Libraries, 65(3): 251-261.

[2] Baca, Murtha, \& Harpring, Patricia, eds. 2006. Categories for the Description of Works. [online]. [cited 2011.11.28]. 
$<\mathrm{http} / / / \mathrm{www}$. getty.edu/research/conducting_research/standards/cdwa/introduction.html $>$.

[3] Bearman, David, \& Geber, Kati. 2007. "Enhancing the role of cultural heritage institutions through new media: Transformational agendas and projects." In Proceedings of International Cultural Heritage Informatics Meeting (ICHIM07). Edited by J. Trant and D. Bearman. Toronto: Archives \& Museum Informatics. [online]. [cited 2011.11.30]. $<\mathrm{http}: / /$ www.archimuse.com/ichim07/papers/bearman/bearman.html>.

[4] Caplan, Priscilla. 2003. Metadata Fundamentals for All Librarians. Chicago, IL: American Library Association.

[5] Elings, Mary, \& Waibel, Gunter. 2007. "Metadata for all: Descriptive standards and metadata sharing across libraries, archives, and museums.” First Monday, 12(3). [online]. [cited 2011.10.15]. $<\mathrm{http} / / /$ www.firstmonday.org/issues/issue12_3/elings/index.html $>$.

[6] Goodman, Nelson. 1976. Languages of Art: An Approach to a Theory of Symbols. Indianapolis: Hackett Publishing Company.

[7] Greenberg, Jane. 2003. "Metadata and the World Wide Web." In Encyclopedia of Library and Information Science. Vol.72, Supplement 35: 1876-1888. New York: Marcel Dekker.

[8] Hillmann, Diane. 2005. Dublin Core Metadata Initiative: Using Dublin Core. [online]. [cited 2011.11.2]. <http://dublincore.org/documents/usageguide/>.

[9] Kalay, Yehuda E., Kvan, Thomas, \& Affleck, Janice, eds. 2007. New Heritage: New Media and Cultural Heritage. Routledge: London.

[10] Lanzi, Elisa, \& McRae, Linda. 2007. "Cataloging cultural objects: Community building through standards." Visual Resources Association Bulletin, 34(1): 15-19.

[11] Nam, Taewoo \& Lee, Seungmin. 2010. "Study on the semantic extension of the concept of metadata." Journal of the Korean Society for Library and Information Science, 44(4): 373-393.

[12] Neugebauer, Tomasz. 2005. "Metadata for image resources." Photography Media Journal, July (2005). [online]. [cited 2011.4.6].

$<\mathrm{http}: / /$ www.photographymedia.com/article.php?page=All\&article=AImageMetadata $>$.

[13] Sundgren, Bo. 1973. An Infological Approach to Data Bases. Ph.D. diss., School of Economics, University of Stockholm, Sweden.

[14] Sundgren, Bo. 1975. Theory of Data Bases. New York: Petrocelli/Charter.

[15] VRA Core Data Standards Committee. 2011. VRA Core 4.0 Introduction. VRA Core Schemas and Documentation. [online]. [cited 2011.9.20].

$<\mathrm{http}: / /$ www.loc.gov/standards/vracore/schemas.html $>$. 


\section{Appendix. Survey Questionnaire for art museums}

\section{Managemental Elements}

\begin{tabular}{|c|c|c|c|}
\hline 요소 & 하위요소 & 사례 & 불필요 \\
\hline \multirow{4}{*}{ 전시력 } & 전시장소 & 작품이 전시된 장소에 대한 설명 (국립현대미술관) & \\
\hline & 전시기간 & 작품이 전시된 기간 (2010.1-2010.11) & \\
\hline & 전시명 & 작품이 전시된 전시회의 이름 (이중섭 추모 전시회) & \\
\hline & 전시주제 & 작품이 전시될 때 부여된 주제 (이중섭 추모) & \\
\hline \multirow{5}{*}{ 대여관리 정보 } & 대여기간 & 작품이 대여되었을 경우, 대여된 기간 (2010.1-2010.11) & \\
\hline & 피대여기관 & 작품을 대여해 간 기관 (이중섭박물관) & \\
\hline & 피대여담당자명 & 작품의 대여에 책임을 지는 담당자 이름 (남영준) & \\
\hline & 피대여담당자 연락처 & 피대여담당자의 연락처 (주소, 이메일주소, 혹은 전화번호) & \\
\hline & 피대여대가 & 작품의 대여와 관련된 비용 ( 100,000 원) & \\
\hline \multirow{5}{*}{$\begin{array}{l}\text { 수집정보 } \\
\text { (현소장 정보) }\end{array}$} & 소유권자 & 현재 작품의 소유권을 지니고 있는 사람 이름 (남영준) & \\
\hline & 수집방법 & $\begin{array}{l}\text { 현재 작품을 소장하고 있는 기관에서 작품을 수집한 방법 } \\
\text { (구입, 기증, 관리전환) }\end{array}$ & \\
\hline & (관내) 소장위치 & $\begin{array}{l}\text { 작품을 소장하고 있는 기관에서 작품을 보관하고 있는 위치 } \\
\text { (수장고 1층) }\end{array}$ & \\
\hline & 구입일 및 가격 & 작품을 구입한 일자 및 가격 (2010.11.29. 100,000원) & \\
\hline & 판매일 및 가격 & 작품을 판매한 경우, 판매일자 및 가격 (2010.11. 100,000원) & \\
\hline \multirow{4}{*}{$\begin{array}{c}\text { 소장력 } \\
\text { (전소장자 정보) }\end{array}$} & 이름 & 작품을 이전에 소장하고 있던 사람의 이름 (남영준) & \\
\hline & 연락처 & 전소장자의 연락처 (주소, 이메일, 전화번호 등) & \\
\hline & 소장권 & 이전에 작품의 소유권을 지니고 있었던 사람 (남영준) & \\
\hline & 디지털화이용 허락여부 & $\begin{array}{l}\text { 저작권 관련 사항으로, 작품에 대한 저작권을 지니고 있는 사람 } \\
\text { (남영준) }\end{array}$ & \\
\hline \multirow{4}{*}{$\begin{array}{l}\text { 관리특이 } \\
\text { 요구사항 }\end{array}$} & 수장시 특이 요구사항 & $\begin{array}{l}\text { 작품을 수장할 때 주의해야 할 사항 혹은 작품을 관리할 때 유의해 } \\
\text { 야 할 사항 (18-25도 사이에서 보관) }\end{array}$ & \\
\hline & 이동시 특이 요구사항 & 작품을 이동할 때 유의해야 할 사항 (무진동차로 이동) & \\
\hline & 전시시 특이 요구사항 & $\begin{array}{l}\text { 작품을 전시할 때 고려하거나 유의해야 할 사항 } \\
\text { (조명의 위치, 작품 전시의 높이 등) }\end{array}$ & \\
\hline & 주제명, 분류명 & $\begin{array}{l}\text { 작품을 전시할 때 부여해야 할 주제 혹은 전시할 때 적용해야 } \\
\text { 할 작품의 범주 (추상화로 분류, 주제: 모성애) }\end{array}$ & \\
\hline \multirow{4}{*}{ 이동정보 } & 이전위치 & $\begin{array}{l}\text { 미술관내에서 작품의 위치를 이동했을 경우, 이동 전의 위치 } \\
\text { (1층 수장고) }\end{array}$ & \\
\hline & 현위치 & 관내에서 현재 작품의 위치 (2층 수장고) & \\
\hline & 이동일시 & 관내에서 작품을 이동한 일시 (2010.11.29) & \\
\hline & 이동사유 & 작품을 이동시킨 이유 (파손 수리 등) & \\
\hline
\end{tabular}




\section{Descriptive Elements}

\begin{tabular}{|c|c|c|c|}
\hline 요소 & 하위요소 & 사례 & 불필요 \\
\hline 작품부문 & 작품의 분류 & 회화, 조각 등 (서양화) & \\
\hline 작품명 & 작품명제 & 작품에 부여된 이름 (서귀포의 환상) & \\
\hline 제작연도 & 제작연도( 월) & 작품의 제작연도 (2010) & \\
\hline \multirow{7}{*}{ 작가정보 } & 이름(본명) & 작가의 본명 (이중섭) & \\
\hline & 이름(필명) & 본명 이외에 작가가 사용하는 필명 (이중섭: 睛海) & \\
\hline & 국적 & 작가의 국적 (대한민국) & \\
\hline & 생몰년 & 작가의 연도 (1961-2010) & \\
\hline & 성별 & 작가의 성별 (남, 여) & \\
\hline & 최종학력 & 작가의 최종학력 (대졸) & \\
\hline & 소속 & 필요할 경우에만 사용 (국립현대미술관) & \\
\hline \multirow{7}{*}{ 작품정보 } & 규격 & 작품의 크기 $(41 \times 71 \mathrm{~cm})$ & \\
\hline & 에디션 & 몇 번째로 제작된 작품인지에 대한 설명 $(2 / 60)$ & \\
\hline & 무게 & 작품의 무게 $(1.5 \mathrm{~kg})$ & \\
\hline & 재질 & 작품의 재질 (나무판) & \\
\hline & 상영시간 & 공연작품의 경우 상영되는 시간 (45분) & \\
\hline & 작품구성정보 & 작품과 관련된 부속물을 설명하는 사항 (받침대) & \\
\hline & 양(시리즈정보) & 작품이 시리즈로 제작될 경우 그 수 (3편) & \\
\hline \multirow{7}{*}{ 작품제작 정보 } & 재료 & 작품의 제작에 사용된 재료 (유채) & \\
\hline & 기법 & 작품의 제작에 사용된 기법 (비닐기법) & \\
\hline & 작가설명 & 작가의 제작의도 (작가가 직접 작성한 작품설명) & \\
\hline & 작품설명 & 작가 이외의 사람이 작품에 대해 부여한 설명 & \\
\hline & 작품의 배경 & 작품이 작성된 시대적, 문화적 배경에 대한 설명 & \\
\hline & 관련자료 & 도록, 영화 등 작품과 관련된 자료 (이중섭 추모음반) & \\
\hline & 기타 & 상기의 사항 이외에 추가되는 항목 & \\
\hline
\end{tabular}

\section{Additional Comments}

※ 앞에서 제안한 내용적 항목, 관리적 항목 이외에 미술작품의 관리나 검색을 위해 필요하다고 생각하시는 요소에 대해서 자유롭게 기술해 주시면 감사하겠습니다. 위의 요소들은 국립현대미술관관련 자료와 $\mathrm{CDWA}$ 를 참조하여 기본적인 내용만을 정리한 것입니다. 전문가 의견수렴과 실제 미술관 방문을 통해 구체적인 요소를 도출할 것입니다. 